\title{
Assessment of susceptibility in local chickpea varieties by the cowpea weevil, callosobruchus maculatus (Coleoptera: Bruchidae)
}

\author{
Nabeela Kouser*, Nasreen Memon, Mansoor Ali Shah, Zoya Saleh, \\ Bhojoo Mal and Dildar Ali Solangi \\ Department of Zoology, University of Sindh, Jamshoro, Sindh-Pakistan \\ *Corresponding author's email: nabeelaaijaz@yahoo.com
}

\section{Citation}

Nabeela Kouser, Nasreen Memon, Mansoor Ali Shah, Zoya Saleh, Bhojoo Mal and Dildar Ali Solangi. Assessment of susceptibility in local chickpea varieties by the cowpea weevil, callosobruchus maculatus (Coleoptera: Bruchidae). Pure and Applied Biology. Vol. 6, Issue 2, pp481-489. http://dx.doi.org/10.19045/bspab.2017.60047

\begin{tabular}{llll}
\hline \hline Received: 07/12/2016 & Revised: 22/03/2017 & Accepted: 24/03/2017 & Online First: 27/03/2017
\end{tabular}

\section{Abstract}

Chickpea is an important pulse food that fulfills the requirement of the staple food. Callosobruchus maculatus (cowpea weevil) is the most important destructive pest that causes severe economic losses in quantity and nutritional quality. The present work is on the susceptibility of cowpea weevil on four main varieties of chickpea of Pakistan (KP-8mm, KC$12 \mathrm{~mm}, \mathrm{KE}-9 \mathrm{~mm}$ and Desi kala chana). The study was conducted for a period of four months from September to December 2015, under room conditions at moderate temperature of $27 \pm 2{ }^{\circ} \mathrm{C}$ and $60 \pm 5 \%$ relative humidity with 12 hour light and dark cycle to produce many generations of cowpea weevil. Ten pairs of newly emerged adults were released in plastic jars having 100 gram of each of four varieties. All the varieties were checked after the interval of fifteen days to observe the intensity of seed damage by the $C$. maculatus. The highest consumption was observed in $\mathrm{KP}-8 \mathrm{~mm}$ and $\mathrm{KC}-12 \mathrm{~mm} 85 \mathrm{gm}$, 79gm respectively, while KE-9 $\mathrm{mm}$ showed relatively low consumption that was $71 \mathrm{gm}$, and Desi kala chana was least consumed $62 \mathrm{gm}$ by cowpea weevil. The susceptible varieties exhibited soft, moreover, smooth seed coat and white in colour whereas least susceptible had hard and wrinkled seed coat. Based on present observation, it is noted that by growing tolerant varieties infestation of chickpea by cowpea weevil can be limited.

Keywords: Susceptibility; Cowpea weevil; Chickpea

\section{Introduction}

Chickpea (cicer arietinum) is a valuable pulse crop belongs to family Leguminosae also known as the pea or bean family. Chickpea contributes about $15 \%$ of the world's total pulse production [1]. In human diet, it is a big source of protein about $20 \%$, which fulfills the protein requirement of the people, especially in rural areas of Pakistan [2]. In Pakistan, it is cultivated on an area of about 985 thousand hectares, which produces about 673 thousand tons of chickpea [3]. Two main types of chickpea differ from each other in seed size, shape 
and colour. The first type is Desi, small and brown seeds and second is Kabuli, with large white colour seeds. In Thal areas of Punjab and Khyber Pakhtunkhwa provinces, it is grown in rainfed conditions as its production totally depends upon rainfall. In Sindh and Baluchistan, it is grown on residual moisture after rice harvest. Thal is the major chickpea-producing region in Pakistan, which alone contributes about $80 \%$ to its production [4, 5]. Every year in developing countries, chickpea seed suffer by notable quantitative and qualitative losses $60 \%$ [6] due to pest attack on chickpea seeds. Nearly about $10 \%$ of chickpea grain loss occurs in Pakistan, due to Callosobruchus species alone in storage [7]. It has been observed that $C$. maculatus is the most destructive pest of chickpea in storage. The larvae feed on the seeds, causing significant damage that affects the chickpea's quality and quantity such as weight loss decreases the grains nutritional value and loses germination capacity [8]. Callosobruchus maculatus is very important pest of field as well as of stored pulses like chickpea, cowpea, red gram, black gram and green gram in all over the tropics [9]. The cowpea weevil can damage whole grain of chickpea and within three months it may cause total loss [10]. Callosobruchus maculatus larvae feed and develop mainly on seed, while the adults do not need any food or water and lives for 10-14 days just for mating and laying eggs on seeds [11]. In heavy infestation by cowpea weevil, the grains become completely hollow, unmarketable and unfit for human consumption. Therefore, there is a need to search for control to avoid the heavy losses of grains by this pest. Investigating the resistant variety is the best option $[12,13]$. The present study is planned to screen susceptibility of four available cultivars of chickpea against cowpea weevil.

\section{Materials and methods Experimental site}

The study was carried out at the insectary of Zoology Department, University of Sindh Jamshoro during September to December 2015.

Infested chickpea seeds were collected from local market of Hyderabad from which adults of $C$. maculatus were collected. The insect adults were brought to the entomology laboratory and identified on the basis of morphological characters. The insects were used to maintain a culture of $C$. maculatus on undamaged chickpea seeds under room conditions at moderate temperature of $27 \pm 2{ }^{\circ} \mathrm{C}$ and $60 \pm 5 \%$ relative humidity in September and October while $22 \pm 3^{\circ} \mathrm{C}$ and $50 \pm 5$ relative humidity in November and December with12 hour light and dark cycle to increase the population of C. maculatus adults. The newly emerged adults kept under observation for experimental purpose.

\section{Experimental procedure}

The experiment was conducted on three varieties of Kabuli chickpea, KP-8mm, KC$12 \mathrm{~mm}, \mathrm{KE}-9 \mathrm{~mm}$ and one variety of Desi chickpea, Desi Kala chana. The fresh seeds of each variety were sterilized by keeping in freezer for one week at $-5^{\circ} \mathrm{C}$ for monitoring of presence of any infestation. The damage of chickpea varieties by $C$. maculatus were examined in no-choice test in which the pest were confined to oviposit and develop on the same variety to which it released. Ten couples of newly emerged adults were taken from culture and introduced in plastic jars having 100 gram of each of four varieties. The jars were covered with aerated muslin cloth and held tightly with rubber band. The insects were free there to damage the seeds and for oviposition. All the varieties were checked after the interval of fifteen days to observe the intensity of seed damage by the C. maculatus. The experiment was conducted for a period of four months from 
September to December 2015 after the release of $C$. maculatus. The variation in damage percentage of each variety was observed by infestation, weight loss (g) and seed coat characteristics.

Seed's morphological characters of each variety were observed on a visual basis. All experiments were conducted under room temperature at $27 \pm 2^{\circ} \mathrm{C}$ and $60 \pm 5 \% \mathrm{RH}$ supported by [14] and $22 \pm 3{ }^{\circ} \mathrm{C}$ and $50 \pm 5 \%$ $\mathrm{RH}$ checked by a thermo hygrometer and a photoperiod of twelve hours.

\section{Results}

The present study showed that the damage of C. maculatus in all chickpea varieties is variable. I placed four commonly used varieties of chickpea, i.e., KP-8mm, KE9mm, KC-12mm and Desi Kala Chana against $C$. maculatus. However, all the varieties were more or less susceptible to cowpea weevil due to various factors. The ratio of susceptibility by insect pests to stored products mainly depends upon variety, insect species, seed size, starch quantity and texture of seed [15]. A variety possess many different morphological characters like grain size, wrinkled or smooth surface, variation in color and seed texture [15]. Our observations about morphological characters of four varieties were agreed to the findings of [16], as our all chosen varieties were different in grain size, wrinkled or smooth surface, colour and texture (Table 01). The variation in morphological characters of varieties can effect on the oviposition of insect pests and their developmental period. The legume seeds (cowpea, chickpea etc) with smooth seed coats were more susceptible to $C$. maculatus as compare to those varieties which had rough seed coats [17]. The bruchid of legume seeds lay eggs in little amount on rough seed coated varieties as compare to smooth seed coated varieties [18]. Usually large size legume seeds are more favorable hosts of cowpea weevil than small size seeds, but in chickpea seeds, thickness of the seed coat is a major physical character that affect to attack of cowpea weevil rather than the size of the seeds [19]. In present study we have noted month wise data of damage on all varieties by cowpea weevil. We found the small size variety i.e. $\mathrm{KP}-8 \mathrm{~mm}$ was the most susceptible variety among all other large and medium size varieties. In the same manner the variety which has more oviposition was highly consumed by cowpea weevil. KP-8mm was small size, soft and smooth seed coated variety which voraciously consumed by cowpea weevil. The highest consumption of cowpea weevil in this variety was recorded in September and October 15 and 35 gram while it remain low in November and December 25 and 10 gram. The total consumption of KP-8mm in four months was recorded 85 gram out of 100 grams. The mean was recorded 21.25 (Table 02 and Figure 01). KC-12mm variety of chickpea was also highly infested by cowpea weevil. It was large size variety had highest consumption 13 and 32 gram in September and October while in November and December the consumption was recorded 24 and 10 gram. The total consumption of this variety by cowpea weevil was recorded 79 gram during whole study period and the mean was recorded 19.75 (Table 3 and Figure 02). KE-9mm was medium size variety had hard texture found moderately susceptible by cowpea weevil. The maximum consumption of KE-9mm was recorded in September and October 11 and 13 gram while lowest in November and December 21 and 8 gram. The total consumption of this variety was recorded 71 gram out of 100 grams. Total mean was found 17.75 (Table 4 and Figure 3). The fourth variety was Desi kala chana had small size, brown colored and hard texture. It was found least susceptible variety against cowpea weevil. In this variety also the 
highest consumption was found in September and October 9 and 25 gram while in November and December the lowest consumption was recorded 19 and 9 gram. Total consumption was recorded 62 gram and the mean was 15.5 (Table 05 and Figure 04). After susceptibility the morphological characters of seed coat had changed which observed in all varieties. The surface of all varieties became rough and porous. Colour was also fade (Table 06). Comparison of total consumption of four varieties shown in (Table 07 and Figure 05). KP-8mm variety of chickpea was highly consumed variety by cowpea weevil 85 gram, KC-12mm was second most consumed variety 79 gram, KE-9mm was moderately consumed 71 gram while Desi Kala Chana was least consumed variety by cowpea weevil 62 gram.

Table 1. Physical Characteristics of Fresh seeds of different chickpea varieties

\begin{tabular}{|c|c|}
\hline Varieties of chickpea & Seed Morphological characteristics (seed coat) \\
\hline KP-8mm & Small size, smooth, white color, soft texture \\
\hline KC-12mm & Large size, smooth, white color, soft texture \\
\hline KE-9mm & Medium size, smooth, white color, hard texture \\
\hline Desi kala chana & Small size, wrinkled, brown color, hard texture \\
\hline
\end{tabular}

Table 2. The consumption of KP-8mm by cowpea weevil (Sep-Oct 2015) at $27 \pm 2^{\circ} \mathrm{C}, 60 \pm 5 \%$ RH (Nov-Dec 2015) at $22 \pm 3^{\circ} \mathrm{C}, 50 \pm 5 \%$ RH (Beetles Reared on 100 grams)

\begin{tabular}{|l|c|}
\hline Months & Total Consumption in grams \\
\hline September & 15 \\
\hline October & 35 \\
\hline November & 25 \\
\hline December & 10 \\
\hline Total Weight Loss & 85 \\
\hline Mean & 21.25 \\
\hline Standard Deviation & 11.08 \\
\hline
\end{tabular}

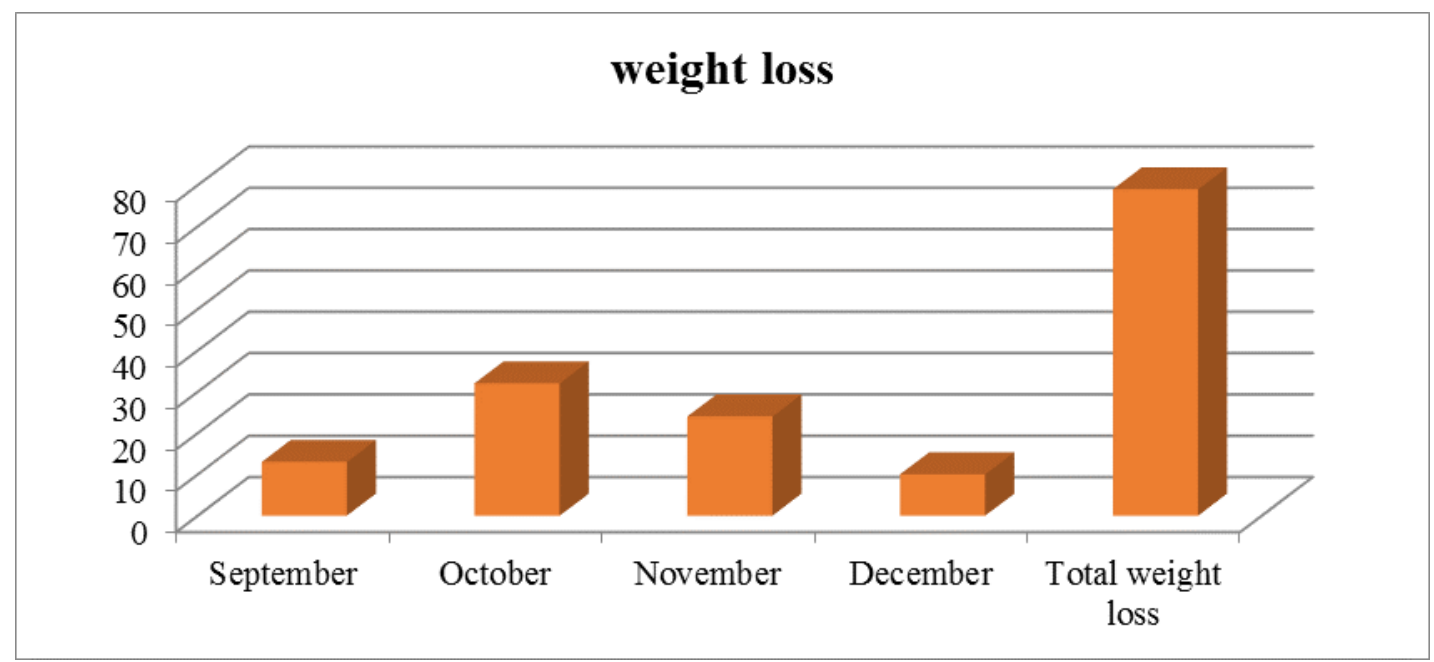

Figure 1. The consumption of KP-8mm by cowpea weevil (September-December 2015) 
Table 3. The consumption of $\mathrm{KC}-12 \mathrm{~mm}$ by cowpea weevil (Sep-Oct 2015) at $27 \pm 2^{\circ} \mathrm{C}$, $60 \pm 5 \%$ RH (Nov-Dec 2015) at $22 \pm 3{ }^{\circ} \mathrm{C}, 50 \pm 5 \%$ RH (Beetles Reared on 100 grams)

\begin{tabular}{|l|c|}
\hline Months & Total Consumption in grams \\
\hline September & 13 \\
\hline October & 32 \\
\hline November & 24 \\
\hline December & 10 \\
\hline Total Weight Loss & 79 \\
\hline Mean & 19.75 \\
\hline Standard Deviation & 10.14 \\
\hline
\end{tabular}

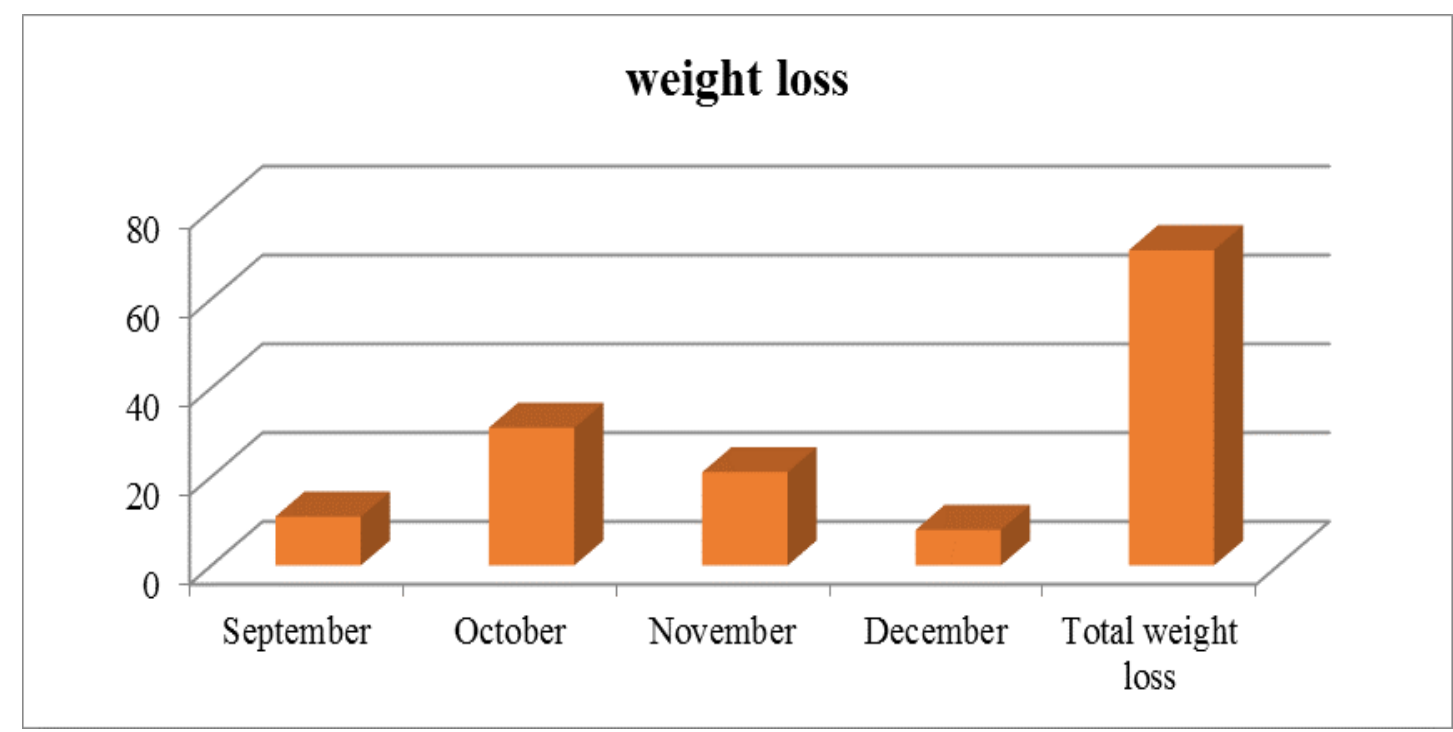

Figure 2. The consumption of KC-12mm by cowpea weevil (September-December 2015)

Table 4. The consumption of KE-9mm by cowpea weevil (Sep-Oct 2015) at $27 \pm 2{ }^{\circ} \mathrm{C}, 60 \pm 5 \%$ RH (Nov-Dec 2015) at $22 \pm 3^{\circ} \mathrm{C}, 50 \pm 5 \%$ RH (Beetles Reared on 100 grams)

\begin{tabular}{|l|c|}
\hline Months & Total Consumption in grams \\
\hline September & 11 \\
\hline October & 31 \\
\hline November & 21 \\
\hline December & 08 \\
\hline Total Weight Loss & 71 \\
\hline Mean & 17.75 \\
\hline Standard Deviation & 10.43 \\
\hline
\end{tabular}




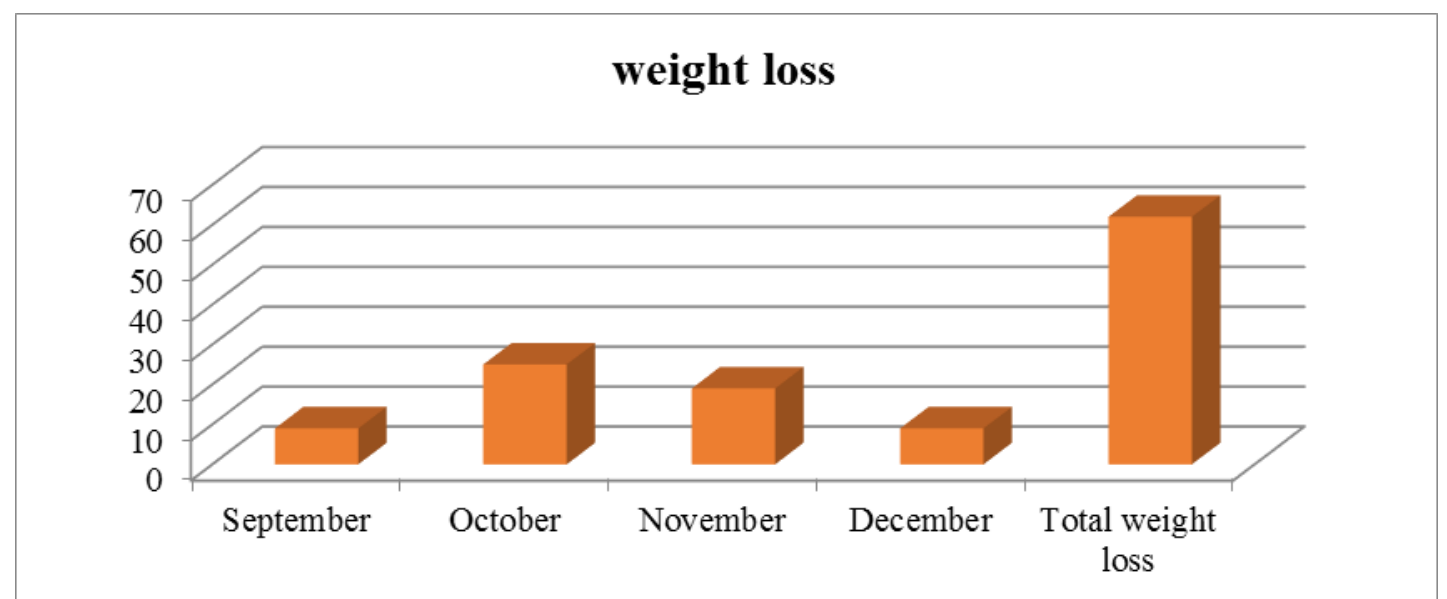

Figure 3. The consumption of KE-9mm by cowpea weevil (September-December 2015)

Table 5. The consumption of Desi Kala Chana by cowpea weevil (Sep-Oct 2015) at $27 \pm 2^{\circ} \mathrm{C}$, $60 \pm 5 \%$ RH (Nov-Dec 2015) at $22 \pm 3{ }^{\circ} \mathrm{C}, 50 \pm 5 \%$ RH (Beetles Reared on 100 grams)

\begin{tabular}{|l|c|}
\hline Months & Total Consumption in grams \\
\hline September & 09 \\
\hline October & 25 \\
\hline November & 19 \\
\hline December & 09 \\
\hline Total Weight Loss & 62 \\
\hline Mean & 15.5 \\
\hline Standard Deviation & 7.89 \\
\hline
\end{tabular}

\begin{tabular}{|l|l|}
\hline \\
\hline
\end{tabular}


Table 7. Month wise weight loss (g) by C.maculatus on different chickpea varieties during September -December 2015

\begin{tabular}{|l|l|l|l|l|l|l|}
\hline \multirow{2}{*}{ Variety } & Initial weight & \multicolumn{3}{|c|}{ Weight loss (g) } & Total weight \\
\cline { 3 - 6 } & on 01-09-2015 & Sep & Oct & Nov & Dec & loss (g) \\
\hline KP-8mm & $100 \mathrm{gm}$ & $15 \mathrm{gm}$ & $35 \mathrm{gm}$ & $25 \mathrm{gm}$ & $10 \mathrm{gm}$ & $85 \mathrm{gm}$ \\
\hline KC-12mm & $100 \mathrm{gm}$ & $13 \mathrm{gm}$ & $32 \mathrm{gm}$ & $24 \mathrm{gm}$ & $10 \mathrm{gm}$ & $79 \mathrm{gm}$ \\
\hline KE-9mm & $100 \mathrm{gm}$ & $11 \mathrm{gm}$ & $31 \mathrm{gm}$ & $21 \mathrm{gm}$ & $08 \mathrm{gm}$ & $71 \mathrm{gm}$ \\
\hline Desi kala chana & $100 \mathrm{gm}$ & $09 \mathrm{gm}$ & $25 \mathrm{gm}$ & $19 \mathrm{gm}$ & $09 \mathrm{gm}$ & $62 \mathrm{gm}$ \\
\hline
\end{tabular}

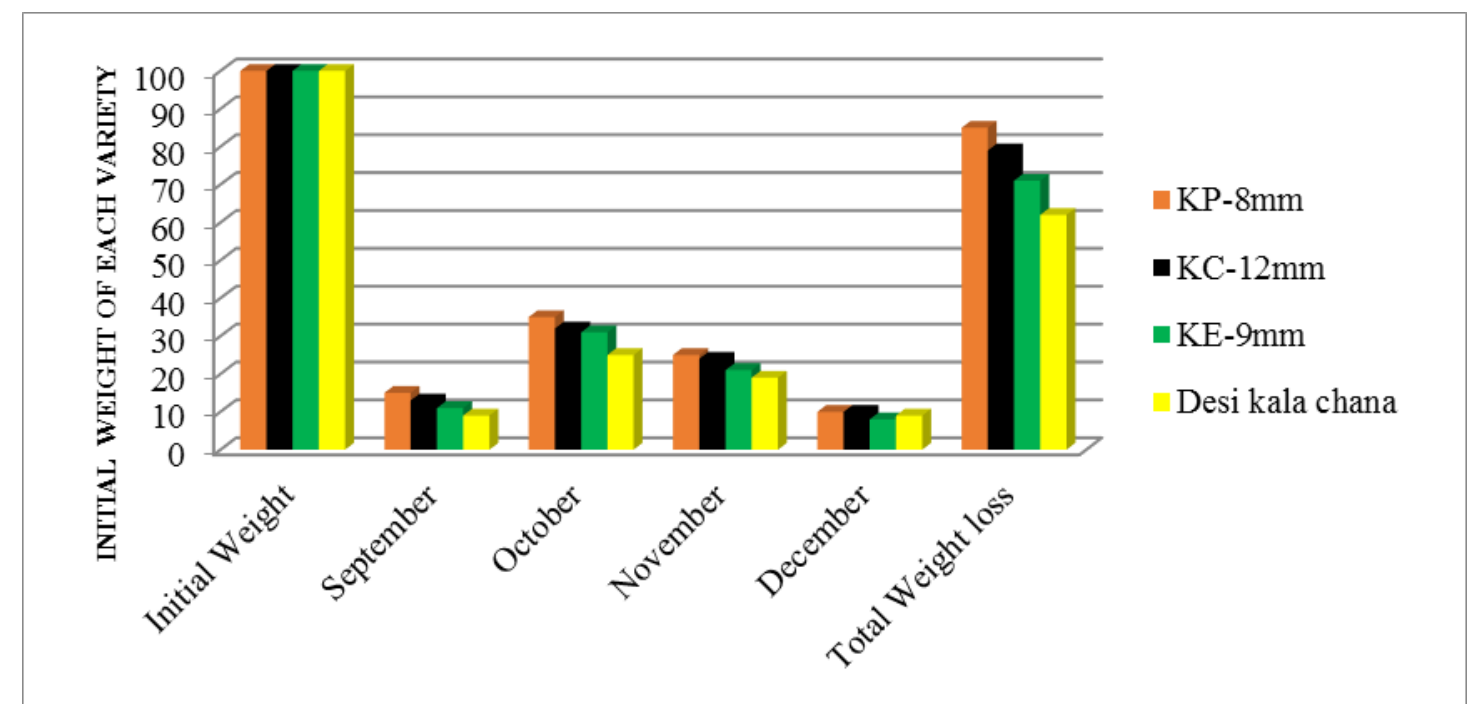

Figure 5. The comparison of total weight loss (gm) by $C$. maculatus on four chickpea varieties during September - December 2015

\section{Discussion}

In present study the experiments were conducted to observe the intensity of cowpea weevil's damage on four varieties of chickpea. The above result showed that all the varieties of chickpea are susceptible to C. maculatus however, varieties with soft, smooth seed coat proved more susceptible as compare with those having hard, wrinkled seed coat. Our results indicated that chickpea susceptibility mostly depends upon thickness of the seed coat than size of grain. KP-8mm variety of chickpea was small in size but we found most susceptibility on it. $\mathrm{KC}-12 \mathrm{~mm}$ was the second most susceptible variety, KE-9mm was moderate susceptible while Desi Kala Chana found least susceptible variety of chickpea against cowpea weevil. Our results revealed that the maximum consumption was recorded in the months of moderate temperature $27-30^{\circ} \mathrm{C}$ and high humidity 60-65\% RH in September and October while lowest consumption was recorded in low temperature $22-25{ }^{\circ} \mathrm{C}$ and low humidity $50-55 \%$ in November and December. It shows that temperature and relative humidity have positive effects on the consumption of chickpea by cowpea weevil. Previous researchers reported the factors which effect on the infestation rate of cowpea weevil like temperature and humidity [20], host size [21], population density [22] and nutritional value of seed [23]. Our results indicated the $27-30^{\circ} \mathrm{C}$ and $60-65 \%$ RH was suitable temperature and humidity for high consumption of chickpea 
by cowpea weevil. As [24] maintained a culture of $C$. maculates on chickpea for their experiment at moderate temperature that was $30 \pm 1^{\circ} \mathrm{C}$ and $60 \pm 10 \mathrm{RH}$. The findings of [25] revealed that, at high temperature $40^{\circ} \mathrm{C}$ or above adult bruchid beetles cannot produce any progeny. Even if we found some extent of survival, the population growth will be very low. At low temperature like $-18^{\circ} \mathrm{C}$, no any life stage of $C$. maculatus could survive, they were died within 14 days [26]. Our all selected varieties of chickpea affected by Temperature and humidity. The susceptibility by this pest can be controlled by growing tolerant varieties which have hard seed coat.

\section{Conclusions}

The results in compilation demonstrate that $\mathrm{KP}-8 \mathrm{~mm}$ and $\mathrm{KC}-12 \mathrm{~mm}$ varieties of chickpea showed highest susceptibility and are not fit for long time storage while KE$9 \mathrm{~mm}$ showed moderate susceptibility and Desi kala chana showed least susceptibility, so they can be kept for long time storage. For the former varieties, necessary measures for their protection against $C$. maculatus may be undertaken.

\section{Authors' contributions}

Conceived and designed the experiments: $\mathrm{N}$ Kouser, N Memon \& MA Shah, Performed the experiments: $\mathrm{N}$ Kouser, Analyzed the data: N Kouser \& N Memon, Contributed reagents/ materials/ analysis tools: $\mathrm{Z}$ Saleh, B Mal \& DA Solangi, Wrote the paper: N Kouser \& N Memon.

\section{References}

1. FAO (Food and Agriculture Organization of the United Nations) (2010). Agricultural production year book.

2. Ahmed K, Khalique F, Khan IA, Afzal M \& Malik BA (1991). Studies on genetic resistance in chickpea (Cicer arietinum L.) to bruchid beetle (Callosobruchus chinesis L.) attack. Pak J Sci and Ind Res 34: 449452.

3. Economic Survey of Pakistan (2012-13). Economic Advisor's Wing, Finance
Division, Government of Pakistan, Islamabad.

4. Reddy AR, Chaitanya KV \& Vivekanandan M (2004). Drought-induced responses of photosynthesis and antioxidant metabolism in higher plants. J Plant Physiol 161: 11891202.

5.Yu LX \& Setter TL (2003). Comparative transcriptional profiling of placenta and endosperm in developing maize kernels in response to water deficit. Plant Physiology 131: 568-582.

6. Labdi M (1995). Etude de la resistance a l'anthracnose (Ascochyta rabiei) chez le pois chiche (Cicer arietinum L.). Study of resistance to anthracnose (Ascochyta rabiei) in chickpea (Cicer arietinum L.). Doctoral thesis. ENSA de Montpellier, France $143 \mathrm{p}$

7. Aslam M (2004). Pest status of stored chickpea beetle, Callosobruchus chinesis (Linnaeus) on chickpea. J Entomol 1: 2833.

8. Ofuya TI \& Reichmuth C (1992). Mortality of the cowpea bruchid, Callosobruchus maculatus (fabricius) in a highly elevated carbon dioxide atmosphere. In: proceedings of the first European conference on Grain Legumes, Angers, France. 365-366.

9.NRI (National Resource Institute) (1996). Insect Pest of Nigerian Crops: Identification, Biology and Control. Chatham, NRI, U.K.

10. Singh SR \& Jackai LEN (1985). Insect pests of cowpea in Africa: their life cycle, economic importance and potential for control. In: Singh SR, Rachiek O, editors. Cowpea Research, Production and Utilization. Wiley Interscience Publications/John Wiley and Sons Ltd, Chichester 217-231.

11. Kergoat GJ, Silvain JF, Delobel A, Tuda M \& Anton KW (2007). Defining the limits of taxonomic conservatism in host-plant use for phytophagous insects: Molecular systematics and evolution of host-plant association in the seed-beetle genus Bruchus Linnaeus (Coleoptera: Chrysomelidae: Bruchinae) 15: 12-45. 
12. Sarwar M \& Tofique M (2006). Resistance variability within gram seeds of different genotypes against the intrusion of cowpea weevil, Callosobruchus analis L. (Bruchidae: Coleoptera). Pakistan Journal of Seed Technology 1(8 \& 9): 27-34.

13. Sarwar M, Ahmed N \& Tofique M (2009). Host plant resistance relationships in chickpea (Cicer arietinum L.) against gram pod borer (Helicoverpa armigera) (Hubner). Pakistan Journal of Botany 41(6): 3047-3052.

14. Siddiqa A, Perveen F, Naz F \& Ashfaque M (2013). Evaluation of resistance in local chickpea varieties against the pulse beetle, Callosobruchus chinensis L. (Coleoptera: Bruchidae). Pak Entomol 35(1): 43-46.

15. Khattak SU, Hamed K, Khatoon MR \& Mohammad T (1987). Relative susceptibility of different moongbean varieties of pulse beetle, Callosobruchus maculatus (F). J Stored Prod Res 23: 139142.

16. Khattak SU, Alam M, Khalil SK \& Hussain N (1991). Response of chickpea cultivars to the infestation of pulse beetle Callosobruchus chinensis (L). Pak J Zool 23(1): 51-55.

17. Nwanze K, Horber E \& Pitts C (1975). "Evidence of ovipositional preference of Callosobruchus maculatus (F) for cowpea varieties", Environmental Entomology 4: 409-412.

18. Nwanze KF \& Horber E (1976). Seed coats of cowpea affect oviposition and larval development of $C$. maculatus (Fab.). Environ Entomol 5: 213-218.

19. Nwanze KF \& Horber E (1975). Laboratory techniques for screening cowpeas for resistance to $C$. maculatus (Fab.). Environmental Entomol 4: 415-419.

20. Chandrakantha J \& Mathavans S (1986). Change in developmental rates and biomass energy in Callosobruchus maculatus (F.) (Coleoptera: Bruchidae) reared on different foods and temperatures. Journal of stored products research 22(2): 71-75.

21. El-Halfawy MA, Nakhla JM \& Isa NH (1972). Effect of food on the fecundity, longevity and development of the southern cowpea weevil Callosobruchus maculatus (F.). Agricultural Research Review 5(91): 67-70.

22. Mansour MM, Helaly MM, El-Kifl AH \& El-Salam A (1975). Effect of various population densities on the bionomics and longevity of Callosobruchus maculatus (Fab.) at different temperatures and relative humidities. Bulletin de la Societe Entomologique d Egupte 59: 183-189.

23. Creadland PF, Dick KM \& Wright AW (1986). Relationships between larval density, adult size and egg production in the cowpea seed beetle Callosobruchus maculatus .Ecological Entomology 11(1): 41-50.

24. Bhalla S, Gupta K, Lal B, Kapur ML \& Khetarpal RK (2008). Efficacy of various non-chemical methods against pulse beetle, Callosobruchus maculatus (Fab.). In: Endure International Conference on Diversifying Crop Protection, 12-15 October 2008, La Grande-Motte, France pp. 1-4.

25. Lale NES \& Vidal S (2003). Effect of constant temperature and humidity on oviposition and development of Callosobruchus maculatus (F.) and callosobruchus subinnotatus (pic) on bambara groundnut, Vigna subterranean (L.) Verdcourt. Journal of Stored Products Research 39: 459-470.

26. Johnson JA \& Valero KA (2003). Use of commercial freezers to control cowpea weevil, Callosobruchus maculatus (Coleoptera: Bruchidae) in organic Garbanzo beans. Journal of Economic Entomology 96: 1952-1957. 